\title{
REVIEW
}

\section{Marco Checchi, The Primacy of Resistance: Power, Opposition and Becoming. London: Bloomsbury Academic, 2021. ISBN: 9781350124462 (e-book).}

With The Primacy of Resistance, Marco Checchi hopes to generate a 'Copernican revolution' in our understanding of Foucault's power-resistance relationship. The traditional view of this takes power to be the primary, affirmative and dominant force, with the majority of Foucault interlocutors either neglecting a discussion on resistance or solely focusing upon its relation to power. ${ }^{1}$ Resistance is therefore considered subordinate, reactionary and determined by the more important, powerful and primary power. Contrary to this, Checchi begins his study of the power-resistance relationship from a neglected perspective of Foucault revealed in a 1982 interview:

If there was no resistance, there would be no power relations. Because it would simply be a matter of obedience. You have to use power relations to refer to the situation where you're not doing what you want. So resistance comes first, and resistance remains superior to the forces of the process; power relations are obliged to change with the resistance. So I think that resistance is the main word, the key word, in this dynamic. ${ }^{2}$

This interview is one of the rare occasions where Foucault directly addresses the primacy of resistance, which may explain its historical neglect. Checchi considers how far we can take such an idea and, because of the limited account given by Foucault, he traces a line of thought which includes La Boétie, Spinoza, Nietzsche, Tronti, and Deleuze. Around these thinkers, Checchi focuses upon four main trajectories, with a chapter dedicated to each, that will help to reveal the primacy of resistance; nature, labour, politics and ontology.

The work opens with a passage from Salvatore Capograssi, a member of the resistance during the Nazi occupation of Italy, whose memoirs are here translated for the first time. Such a resistance is given as an example of the traditional and common understanding, Resistance with a capital $R$, as a reactive event which causes a temporary fracture to the

\footnotetext{
${ }^{1}$ See Nicos Poulantzas, State, Power, Socialism (1978); Mark Philp, “Foucault on power: A problem in radical translation?" Political Theory 11:1 (1983); Lois McNay, Foucault: A Critical Introduction (1994).

2 Michel Foucault, Ethics: Subjectivity and Truth. Essential Works of Foucault 1954-1984 (1997), 167.
} 
dominant power structure. If the Resistance is successful, it is soon replaced by another stable and dominant power structure or, as usually happens, the Resistance is quickly crushed. Such a view not only reaffirms the primacy of power, which Resistance is born from, defined by and ends with, but also reveals the paradoxical nature of Resistance seeking its own end. Opposing this, throughout his memoirs, Capograssi states that resistance against fascism actually began in 1919 and continued long after 1945; it was a "lifetime engagement" (p. 2). Capograssi's resistance is the primary, creative, continuous and affirmative force of life. Reducing it to a temporary and reactive event cancels "the possibility of thinking resistance as expansion: proliferation, creation, openings, becomings" (p. 5). It will be this that The Primacy of Resistance seeks to reveal.

Readers expecting a focus upon concrete historical examples of Resistance, an expectation that is fueled by the early discussion on Capograssi and the operaismo (workerism) movement, will be disappointed. Resistance, with the capital R, is barely touched upon and, apart from a brief call to arms in the conclusion, it is hard to see the work making, or motivating, an appearance at the barricades. But, as the work progresses, we soon learn that this is because Checchi wants to escape this traditional understanding of resistance. When we reach the theoretical conclusion of resistance as creativity and affirmation, then the practical applications do become clear.

Staying true to a Foucauldian framework, Checchi embarks upon a historical analysis of the primacy of resistance. This begins in chapter two with a discussion on Étienne de La Boétie's theory of 'natural companionship,' which is coupled with resistance. La Boétie considers the primary state of nature to be one of solidarity, cooperation and freedom, with this also securing it as prior to power. The historical inversion of placing power as primary to companionship, and later resistance, was due to humanity entering into 'voluntary servitude.' Checchi illustrates this through a critique of thinkers such as Hobbes and Rousseau up to Rawls and Nozick. Such consensual contractual theories present freedom as something granted, restricted and secondary to a primary power. Such theories do not realise that this power rests upon us relinquishing our natural freedom, of misusing our nature, which leads to our 'denaturation.' Although critiques of power can be noted in these thinkers, they fall into the trap of the "art of not being governed like that," Resistance with a capital. In contrast to this, the state of nature and the primacy of resistance practice the "more radical and absolute art of not being governed at all" (p. 52). Checchi humorously summarises this with the conclusion; "if Hobbes's Leviathan were recorded on vinyl, when played backwards it would have revealed the masked message: 'resistance comes first'” (p.69).

La Boétie's ideas would go on to influence Autonomist Marxism and the operaismo movement that thrived in Italy during the mid-20th century. Mario Tronti was a key figure within these and in chapter three Checchi begins from Deleuze's suggestion that "in Foucault, there is an echo of Mario Tronti's interpretation of Marxism."3 Tronti inverted the Marxist labour-capital relationship by placing labour and working struggles

${ }^{3}$ Gilles Deleuze, Foucault (2006), 120. 
as primary to capital by revealing the latter's dependence and birth from the former. This guarantees the freedom, creativity and primacy of labour, which has been historically inverted by the exploitation and subordination of capital. Checchi traces this history to the contemporary neoliberal 'biofinancialization' of labour. Here, labour is reduced from an originally creative, affirmative and cooperative activity and is engulfed, alongside everything else within and including society, by capital. From this another original revelation of the primacy of resistance is also revealed that the traditional view neglects; resistance does not seek, or even need, opposition. The reactive power, which is itself a resistance to the original creative resistance, is but a "tedious burden" (p. 16). Checchi gives the examples of colonialism and operaismo; how the natives were primary to the colonialists and the workers struggle to capital. Such an idea also finds striking relevance in contemporary matters, such as environmental struggles, but these are sadly left undiscussed.

The notion that power is a reactive force can be found throughout Foucault's body of work: it is "an action upon an action" and a "management of possibilities." 4 Chapter four is the least controversial and original part of the book as it expands upon the reactive nature of power, but readers can still find interest in the dialogue Checchi reveals between Foucault and Spinoza, who is discussed via Ranciere's and Negri's interpretations. The binary of resistance-power is analogised with Ranciere's politics-police and Spinoza's potentia-potestas. Similarities are found between resistance, politics and potentia in their creativity, continuity and openness, whereas their opposition seeks stability, domination and totality. Being, which is here presented as a hybrid of politics, potentia and resistance, is a continuous, spontaneous and dynamic flux and therefore must be "a physics of resistance." 5 Power, police or potestas is now the temporary and reactive fractious event, an interruption to the ever dynamic, transformative and possibility of being.

In chapter five, Checchi turns again to Deleuze to reveal the ontological primacy of resistance and give further proof of its active and creative nature. Whereas a clear and brief background is offered to other writers who may be unfamiliar to the reader, a basic understanding of key Deleuzian concepts, such as 'virtuality' and 'war machine,' are required. It is in Deleuze's Foucault where the primacy of resistance is first emphasised and most clearly formulated. ${ }^{6}$ This reveals that Checchi depends as much on Deleuze as he does Foucault; the primacy of resistance is revealed through their intertwining. Following Deleuze's interpretation, power is confined to the 'actual,' whereas resistance always brings with it possibilities which are found in the 'virtual' or outside. Resistance, although finding itself outside, also bears effect upon the 'actual' in its possibilities and the actualization of these which will go on to transform the 'actual.' Even if no resistance can be perceived, there is always "the distant roar of the battle," 7 thus revealing the 'transversality' of resistance. Leaning upon Nietzschean terminology, resistance is now

\footnotetext{
${ }^{4}$ Michel Foucault, Power. Essential Works of Foucault 1954-1984 (2001), 340-341.

${ }^{5}$ Antonio Negri, The Savage Anomaly: The Power of Spinoza's Metaphysics and Politics (1991), 226.

6 "[Foucault's] final word on power is that it comes first" (Deleuze, Foucault, 89).

${ }^{7}$ Michel Foucault, Discipline E Punish: The Birth of the Prison [1975] (1995), 308.
} 
revealed to be an 'active' force and therefore primary, whereas power is 'reactive' and secondary. The ontological primacy of resistance, and historical analysis that has been traced throughout, reveals a diagram of creativity, possibility, continuous transformation and becoming. This is an optimism that, in the conclusion, Checchi aligns with several contemporary struggles that seek to overcome and transform dominant power relations.

A question that continuously confronts Checchi is whether he widens the scope of resistance to an extremity that escapes the Foucauldian framework. Although Checchi states at the beginning that the primacy of resistance is only an intuition that he tries to transform into a fully formed concept, unacknowledged Foucault statements, such as "there is no escaping from power," or "power is everywhere," 8 haunt the book. These seem to contradict Checchi's claim that resistance can do without power, that power is only a 'tedious burden,' while also doubting his claim that power is confined to the 'actual.' Checchi seems to restrict the productivity and creativity of power that Foucault mentions, and it must be remembered that he mentions these qualities as belonging to power much more frequently than with resistance. Likewise, the work seems to rest upon the presupposition of taking La Boétie's idea of 'natural companionship' as granted. We are presented with an extremely idealistic view of nature where inequalities are naively given as an opportunity to help those who are weaker. A work concentrating on the primacy of power would surely offer the contrary Darwinian view and be able to present support for such a view that is sadly lacking here.

Problems such as these are bound to appear whenever a long-held position is confronted with a 'Copernican revolution,' but such revolutions also bring advantages. In acknowledging the primacy of resistance, we are reminded that political and ethical action must not consist of the reactive form, but that we must utilise its creative and dynamic nature to create new 'diagrams' and relations. The Primacy of Resistance reveals the endless possibilities and ever-open door of socio-political change, action and ethics. Consequently, it can also be used to escape the charge of pessimism or moral relativism that Foucault is often criticised for.

The Primacy of Resistance realises an important step in recognizing an oft-neglected part of Foucault's work while also opening it up to new perspectives and possibilities. Whether Checchi takes it to an extreme is an interesting debate to be had, and while others will surely disagree with the premise and find much counter evidence from within Foucault's work, this reveals one of many avenues that the book can stimulate. Another is the interesting dialogue that is to be had between Foucault and La Boétie, which has only just begun to be explored ${ }^{9}$ and feels the most underdeveloped part of the work. While Foucault uncovered a genealogy of power, the whole theory of resistance, its history, relation to power, society and history, remains unexplored. Foucault traces a clear historical line of power through pastoral, sovereign and disciplinary to biopower, but the work spends surprisingly little time on resistance's relation and influence upon this;

${ }^{8}$ Michel Foucault, The History of Sexuality: Volume 1: An Introduction [1976] (1978), 82-93.

${ }^{9}$ See Marc Schachter, “Foucault and La Boétie," Storia del pensiero politico 5:2 (2016), 241-259. 
especially as this seems to reveal the following power as a resistance to the prior dominant power. For example, when do the techniques and strategies of disciplinary power, which destabilise the dominant structures of sovereign power, stop being resistance and become power?

The Primacy of Resistance is a beginning and foundation from which to develop such theories. Checchi has opened the door and is welcoming us in. His conclusion is not a conclusion per se but, like resistance itself, "an opening, a multiplicity of new creation, resistant re-existences" (p. 24). This makes the work a welcome contribution to the contemporary field of Foucault studies and also creates a new and rich avenue of possible further study. While Foucault has long been described as the "philosopher of power,"10 if we are to take Checchi's interpretation seriously, he must become the 'philosopher of resistance.'

\section{References}

Berseni, Leo, "Michel Foucault: Philosopher of Power," washingtonpost.com, https://www.washingtonpost.com/archive/entertainment/books/1981/03/15/michelfoucault-philosopher-of-power/3cc27899-6c0f-4b60-a8a5-007e112ef9ae/ (accessed July 5th 2021).

Deleuze, Gilles, Foucault. Minneapolis: University of Minnesota Press. 2006.

Foucault, Michel, Discipline and Punish. The Birth of the Prison, trans. Alan Sheridan. New York: Vintage Books, 1995.

Foucault, Michel, Ethics: Subjectivity and Truth. Essential Works of Foucault 1954-1984, trans. Robert Hurley and Others, ed. Paul Rabinow. New York: New Press, 1997.

Foucault, Michel, The History of Sexuality: Volume 1: An Introduction, trans. Robert Hurley. New York: Pantheon Books, 1978.

Foucault, Michel, Power. Essential Works of Foucault 1954-1984, trans. Robert Hurley and Others, ed. James D. Faubion. New York: New Press, 2001.

McNay, Lois, Foucault: A Critical Introduction. Cambridge: Polity Press, 1994.

Philp, Mark, “Foucault on power: A problem in radical translation?" Political Theory 11:1 (1983) 29-52. https://doi.org/10.1177/0090591783011001003

Poulantzas, Nicos, State, Power, Socialism. London: New Left Books, 1978.

Schacther, Marc, "Foucault and La Boétie," Storia del pensiero politico 5:2 (2016), 241-259. https://www.rivisiteweb.it/doi/10.4479/84206

${ }^{10}$ Leo Berseni, “Michel Foucault: Philosopher of Power," washingtonpost.com https://www.washingtonpost.com/archive/entertainment/books/1981/03/15/michel-foucault-philosopherof-power/3cc27899-6c0f-4b60-a8a5-007e112ef9ae/ (accessed July 5th 2021). 
Author info

Tomas Pewton

pewtont@gmail.com

Department of Philosophy

Sofia University

Bulgaria 